\title{
Whole and ground grain sorghum and the free choice feeding system in broiler diets
}

\section{Sorgo grão inteiro e moído e o sistema de livre escolha (free choice feeding) em dietas de frangos de corte}

\author{
Cleber Fagundes ${ }^{1 *}$; Evandro de Abreu Fernandes ${ }^{2}$; Fernanda Heloisa Litz ${ }^{3}$
}

\begin{abstract}
This experiment evaluates the zootechnical performance, yield of cuts, carcass composition, and intake of metabolizable energy, lysine, and methionine + cystine in male broilers from 21 to 42 days of age fed diets based on whole and ground grain sorghum and corn. A total of 112 birds of the Cobb 500 lineage were divided into 28 cages (four animals per cage) in a completely randomized design with four treatments and seven replications. Treatments consisted of diets based on ground corn and soybean meal (control, T1), ground sorghum and soybean meal (treatment 2, T2), whole grain sorghum and soybean meal (treatment 3, T3), and the diet T3 separated in feeders in the fractions (a) whole grain sorghum and (b) concentrate containing the other ingredients of the mixed feed (free choice feeding) (treatment 4 , T4). The variables feed intake, body weight, feed conversion, viability, breast, drumstick and thigh yield, bromatological composition of breast and drumstick + thigh, and daily intakes of metabolizable energy, lysine and methionine + cystine were studied. The whole grain sorghum in diets is viable, contributes to reducing factory and logistics costs in the poultry industry, and promotes the same results of zootechnical performance, yields, and bromatological composition of cuts when compared to diets with ground corn and sorghum. Diets with whole grain sorghum in the free choice feeding system may be a viable alternative because birds sought to meet their daily needs for metabolizable energy and digestible amino acids even in short periods of adaptation to the diets, as demonstrated in the experiment.
\end{abstract}

Key words: Feeding. Birds. Free choice. Nutrition. Whole grain sorghum.

\section{Resumo}

Este experimento avalia o desempenho zootécnico, o rendimento de cortes, composição de carcaça e consumo de energia metabolizável, lisina e metionina + cistina em frangos de corte machos arraçoados, dos 21 aos 42 dias de idade, com diferentes dietas à base de sorgo grão inteiro, moído e milho. Foram utilizadas 112 aves da linhagem Cobb 500 divididas em 28 gaiolas, quatro por gaiola, em um delineamento inteiramente casualizado, com quatro tratamentos e sete repetições, sendo: testemunho (T1) contendo: ração à base de milho moído e farelo de soja; tratamento 2 (T2) ração à base de sorgo moído e farelo de soja; tratamento 3 (T3) ração à base de sorgo grão inteiro e farelo de soja e o tratamento 4 (T4) ração T3 separada em comedouros na fração (a): sorgo grão inteiro e na fração (b): concentrado contendo

1 Discente, Curso de Mestrado, Programa de Pós-Graduação em Ciências Veterinárias, Universidade Federal de Uberlândia, UFU, Uberlândia, MG, Brasil. E-mail: fagundes_cleber@yahoo.com.br

2 Prof. Dr., Programa de Pós-Graduação em Ciências Veterinárias, UFU, Uberlândia, MG, Brasil. E-mail: evandro.fernandes@ufu. br

3 Discente, Curso de Doutorado, Programa de Pós-Graduação em Ciências Veterinárias, UFU, Uberlândia, MG, Brasil. E-mail: fernandalitz@veterinaria.med.br

* Author for correspondence 
os demais ingredientes da ração misturados (sistema de livre escolha). Foram estudados, consumo de ração; peso vivo; conversão alimentar; viabilidade; rendimentos de peito; coxa e sobrecoxa; composição bromatológica de peito e coxa com sobrecoxa ; consumos diários de energia metabolizável, lisina e metionina + cistina. $\mathrm{O}$ uso dosorgo grão inteiro nas dietas é viável e contribui para reduzir os custos fabris e logísticos na indústria avícola e promove os mesmos resultados de desempenho zootécnico, rendimentos e composição bromatológica de corte, comparativamente com as dietas com milho e sorgo moídos. As dietas com sorgo grão inteiro em sistema de livre escolha pode ser uma alternativa viável, pois as aves procuraram suprir suas necessidades diárias de energia metabolizável e aminoácidos digestíveis mesmo em períodos curtos de adaptação as dietas, demonstrado no experimento.

Palavras-chave: Arraçoamento. Aves. Livre escolha. Nutrição. Sorgo grão inteiro.

\section{Introduction}

Nutritionists continually search for economically viable alternatives to broiler feed since it represents approximately $64 \%$ of the cost of poultry production (CARVALHO et al., 2008). The use of alternative foods to improve broiler performance, such as sorghum without tannin, has been one of these alternatives of the poultry industry.

Corn is the main energy source in broiler feeds, accounting for 60 to $70 \%$ in poultry feed formulations (ZANOTTO et al., 1996), but it can be partially or totally replaced by cheaper and feasible raw materials in order to decrease feed costs. Sorghum is very similar to corn regarding its nutritional composition (VALADARES FILHO et al., 2001), especially in its composition of starch, which allows the substitution of corn by sorghum in chicken diets.

According to Rostagno et al. (2011), sorghum has $3,189 \mathrm{kcal} / \mathrm{kg}$ metabolizable energy (ME), 8.97\% crude protein, $2.96 \%$ ethereal extract, $63.24 \%$ starch, $2.30 \%$ crude fiber, and $1.41 \%$ ash. Corn, on the other hand, has 3,381 kcal/kg metabolizable energy (ME), $7.88 \%$ crude protein, $3.65 \%$ ethereal extract, $62.66 \%$ starch, $1.73 \%$ crude fiber, and $1.27 \%$ ash. Therefore, sorghum has only $5.68 \%$ less metabolizable energy for birds when compared to the metabolizable energy of corn.

New studies with whole grain sorghum have also demonstrated the economic viability of using it in the feeding of broilers (CAROLINO, 2012; FERNANDES et al., 2013; SILVA et al., 2014).
Another economically important aspect in the poultry industry with the use of whole grains in the feed is the reduction of manufacturing costs since the electrical energy used in the grinding process represents the second highest cost in the industry (BIAGI, 1998). Moreover, the grinding costs can represent up to $30 \%$ of the feed costs (DOZIER, 2002; SILVA et al., 2014). Whole grain-based broiler diets have gradually become a constant practice in Brazil, Canada, Europe, and Australia, especially because of the known benefits present in this form of feeding (FARUK, 2010; LIU et al., 2014).

The free choice feeding system consists of the feeding in which the whole grain and the concentrated fraction are offered in separate feeders, allowing the birds to choose the amount consumed between both foods (POUSGA et al., 2005).

The aim of this study was to evaluate the zootechnical performance, the yield of cuts, carcass composition, and intake of metabolizable energy, lysine, and methionine + cystine in male broilers from 21 to 42 days of age fed diets based on whole and ground sorghum and under the free choice feeding system.

\section{Material and Methods}

The experiment was conducted in an experimental shed located in the Federal University of Uberlândia (UFU). A total of 112 male broilers of the Cobb 500 strain from an integrating company in Patos de Minas, Minas Gerais, were housed at 21 days of age. All animals were vaccinated against 
Marek and Gumboro in the hatchery. The birds were housed in cages $(50 \times 50 \times 50 \mathrm{~cm})$ with lateral drinking and feeding troughs with dimensions of 50 $\times 10 \times 7 \mathrm{~cm}$. The cages were stacked three by three and arranged in the center of the aviary, each with four birds. The aviary consisted of masonry, fiber cement tiles, laterally closed by a wire mesh, lined with plastic fabric for aviaries, internal and external curtains, and cemented floor. The ambiance control was performed with the use of laterally arranged fans, sprayers, and a thermo-hygrometer.

The experimental design was a completely randomized design with four treatments and seven replications. Treatments consisted of diets based on ground corn and soybean meal (control, T1), ground sorghum and soybean meal (treatment 2, T2), whole grain sorghum and soybean meal (treatment 3, T3), and the diet T3 separated in feeders in the fractions (a) whole grain sorghum and (b) concentrate containing the other feed ingredients properly mixed (free choice feeding) (treatment 4, T4). The feeders of the treatment T4 were divided in half ( 24 $\mathrm{cm}$ for each side) by a cardboard blade $(1 \mathrm{~cm})$ and bilaterally fixed with two plastic seals.

Feeds were formulated with sorghum, corn, and soybean meal according to the nutritional requirements of broilers, being isoenergetic and isonutrients, as in Rostagno et al. (2011). The feed ingredients were submitted to bromatological analyses in the Laboratory of Analysis of Raw Material and Feed (LAMRA) of the Faculty of Veterinary Medicine of UFU. The feeds were produced with a horizontal mixer and grinding sieves with $4.0 \mathrm{~mm}$ drilling. In addition, the particle size (MGD: mean geometric diameter of particles, in micra: $\mu$ ) of the feeds were measured, with values of 889 for T1, 1177 for T2, and 1699 for T3, and T4, consecutively in the growth and final feeds.

The nutritional and energetic levels, as well as the food composition of the feeds for the growth and final phases, are shown in Table 1.

A 24-hour light program was provided in the period of 21 to 28 days of age and 22 hours of light with two hours of darkness in the period of 29 to 42 days of age. Bird feeding was carried out twice a day at 07:30 and 15:00, with potable water and feed ad libitum.

Bird weighing and the number of birds per cage were measured on days $21,28,35$, and 42 using a Kern CH15K20 scale (20 grams precision). Daily feed intake was measured. The performance variables feed intake, body weight, viability, and corrected feed conversion were calculated from these data. To calculate the corrected feed conversion, the ratio between feed intake and weight gain in the period (week) was used, being added weight of dead birds and subtracted the initial weight of birds at the beginning of the period.

On the 43rd day, the birds fasted for 12 hours and six were slaughtered per treatment, totaling 24 birds for the analysis of yield and composition of cuts. These birds were stunned and euthanized by exsanguination. The cuts were weighed on a Balmak M25 scale (five-gram precision) to determine the yield of carcass and cuts: complete breast weight with skin and bone and breast without skin and bone, drumsticks, thighs, and wings. Yields of cuts were composed as a percentage of live weight without feathers.

For the bromatological composition, the breast, drumstick, and thigh were stored frozen and sent to the laboratory for analyses of the centesimal composition. The samples were ground in an electric meat grinder model PCP-22L, homogenized, and a portion of $200 \mathrm{~g}$ was taken and pre-dried in a forced ventilation oven at $65^{\circ} \mathrm{C}$ for 72 hours.

After drying, the analyses of dry matter, ethereal extract, mineral matter and crude protein were carried out. The dry matter was determined by the gravimetric method, based on the weight loss of the material subjected to heating at $105^{\circ} \mathrm{C}$ until constant weight. The ethereal extract (lipid) was determined using the Soxhlet (gravimetric) method, which is based on the amount of material solubilized by the 
solvent. The protein fraction was determined by the Kjeldahl method, which consists of the digestion, distillation, and subsequent titration to determine the total percentage of nitrogen, being multiplied by the mean correction factor of 6.25 (SILVA; QUEIROZ, 2002). All analyses were performed in duplicate.

Table 1. Ingredients, composition and nutritional levels of the experimental diets of fattening (21 to 35 days) and slaughter (36 to 42 days) phases, Uberlândia, 2014.

\begin{tabular}{|c|c|c|c|c|c|c|c|c|}
\hline \multirow{3}{*}{ Ingredients $(\%)$} & \multicolumn{8}{|c|}{ EXPERIMENTAL DIETS } \\
\hline & \multirow[b]{2}{*}{$\mathrm{T} 1$} & \multicolumn{3}{|c|}{ Fattening } & \multicolumn{4}{|c|}{ Slaughter } \\
\hline & & $\mathrm{T} 2$ & $\mathrm{~T} 3$ & $\mathrm{~T} 4$ & $\mathrm{~T} 1$ & $\mathrm{~T} 2$ & $\mathrm{~T} 3$ & $\mathrm{~T} 4$ \\
\hline Sorghum 8,8 & - & 53.86 & 53.86 & 53.86 & - & 49.87 & 49.87 & 49.87 \\
\hline Corn 8,6 & 59.50 & - & - & - & 62,77 & - & - & - \\
\hline Soybean meal 45 & 32.28 & 35.06 & 35.06 & 35.06 & 29.15 & 38.34 & 38.34 & 38.34 \\
\hline Soybean oil & 4.83 & 7.81 & 7.81 & 7.81 & 5.05 & 9.09 & 9.09 & 9.09 \\
\hline Dicalcium phosphate & 1.36 & 1.32 & 1.32 & 1.32 & 1.12 & 1.06 & 1.06 & 1.06 \\
\hline Limestone & 0.77 & 0.76 & 0.76 & 0.76 & 0.70 & 0.66 & 0.66 & 0.66 \\
\hline Salt & 0.42 & 0.44 & 0.44 & 0.44 & 0.43 & 0.43 & 0.43 & 0.43 \\
\hline PX fatt. ${ }^{1}$ & 0.20 & 0.20 & 0.20 & 0.20 & - & - & - & - \\
\hline PX slaug. $^{2}$ & - & - & - & - & 0.30 & 0.30 & 0.30 & 0.30 \\
\hline L-lysine & 0.25 & 0.19 & 0.19 & 0.19 & 0.25 & 0.00 & 0.00 & 0.00 \\
\hline DL-Methionine & 0.27 & 0.28 & 0.28 & 0.28 & 0.24 & 0.20 & 0.20 & 0.20 \\
\hline L-Threonine & 0.07 & 0.04 & 0.04 & 0.04 & 0.00 & 0.00 & 0.00 & 0.00 \\
\hline Total & 100.00 & 100.00 & 100.00 & 100.00 & 100.00 & 100.00 & 100.00 & 100.00 \\
\hline \multicolumn{9}{|l|}{ Nutrients } \\
\hline Metabolizable energy (kcal/kg) & 3.200 & 3.200 & 3.200 & 3.200 & 3.250 & 3.250 & 3.250 & 3.250 \\
\hline Crude protein (\%) & 21.09 & 21.09 & 21.09 & 21.09 & 19.04 & 19.04 & 9.04 & 19.04 \\
\hline Calcium (\%) & 0.75 & 0.75 & 0.75 & 0.75 & 0.66 & 0.66 & 0.66 & 0.66 \\
\hline Available phosphorus (\%) & 0.35 & 0.35 & 0.35 & 0.35 & 0.30 & 0.30 & 0.30 & 0.30 \\
\hline Sodium $(\%)$ & 0.21 & 0.21 & 0.21 & 0.21 & 0.21 & 0.21 & 0.21 & 0.21 \\
\hline Lysine. (\%) & 1.13 & 1.13 & 1.13 & 1.15 & 1.06 & 1.06 & 1.06 & 1.06 \\
\hline Digestible Mhetionine (\%) & 0.56 & 0.56 & 0.56 & 0.56 & 0.51 & 0.50 & 0.50 & 0.50 \\
\hline Digestible Mhet+Cystine (\%) & 0.82 & 0.82 & 0.82 & 0.82 & 0.77 & 0.85 & 0.85 & 0.85 \\
\hline Digestible Threonine (\%) & 0.73 & 0.73 & 0.73 & 0.73 & 0.62 & 0.73 & 0.73 & 0.73 \\
\hline Digestible Tryptophan(\%) & 0.25 & 0.25 & 0.25 & 0.25 & 0.20 & 0.26 & 0.26 & 0.26 \\
\hline Digestible Arginine (\%) & 1.28 & 1.28 & 1.28 & 1.28 & 1.14 & 1.37 & 1.37 & 1.37 \\
\hline
\end{tabular}

T1: diet based on ground corn and soybean meal. T2: diet based ground sorghum and soybean meal. T3: diet based whole grain sorghum and soybean meal. T4: diet based whole grain sorghum and concentrate separated in the feeder (free choice feeding). ${ }^{1}$ PX MC-Mix Fattening (composition per kilogram of feed) - Methionine: 386,1g; Choline: 54,81g; Vit A: 2250000UI; Vit D3: 400000UI; Vit E: 3500UI; Vit K3: 375mg; Vit B1:250mg; Vit B2: 1000mg; Vit B6: 450mg; Vit B12: 3000mcg; Niacin: 7500mg; Pantothenic Acid: 2070mg; Folic Acid: 75mg; Biotin: 12,5mg; Fe: 7500mg; Cu: 2250mg; Mn: 15g; Zn: 15g; I: 250mg; Se: 62,5mg; Avilamycin: 2500mg; Salinomycin: 15g. ${ }^{2}$ PX MC-Mix Slaughter (composition per kilogram of feed): Methionine: 301,95g; Choline: 43,48g; Vit A: 900000UI; Vit D3: 150000UI; Vit E: 1500UI; Vit K3: 150mg; Vit B1:90mg; Vit B2: 300mg; Vit B6: 120mg; Vit B12: 900mcg; Niacin: 1500mg; Pantothenic Acid: 1104mg; Biotin: 4,5mg; Fe: 10g; Cu: 3000mg; Mn: 20g; Zn: 20g; I: 333,33mg; Se: 60mg. 2 DSO: Degummed Soybean Oil; CCOHA: Crude Corn Oil with High Acidity. 
The experimental design was a completely randomized design with four treatments, seven replicates, and four birds per experimental unit. The variables of zootechnical performance, yield, and bromatological composition of cuts, after verifying the homogeneity of variances and normality of residuals, were submitted to analysis of variance (ANOVA) and the means were compared by the Scott-Knott test $(\mathrm{P}<0.05)$ using the statistical program SISVAR (FERREIRA, 2008).

The statistical analysis of the intake of metabolizable energy, lysine, and methionine + cystine was determined by means of second-degree polynomial equations by adopting the time ( 21 to 42 days) as the independent variable. The significance of the equation was verified using the p-value of the analysis of variance (ANOVA) of the second- degree model by adopting a 5\% significance. The coefficient of determination of each equation was also analyzed.

The comparison of the parameters intake of metabolizable energy, lysine, and methionine + cystine used the confidence intervals of the estimates of coefficients of the regression equation, constructing graphs in the Microsoft Excel program. These analysis procedures were performed in the statistical program SISVAR (FERREIRA, 2008).

\section{Results and Discussion}

Table 2 shows the results of the zootechnical performance feed intake, weight gain, feed conversion, and viability in the period from 21 to 28 days of age in the four treatments.

Table 2. Performance of Cobb 500 broilers of 21 to 28 days submitted to different diets, Uberlândia, 2014.

\begin{tabular}{ccccc}
\hline \multirow{2}{*}{ Diets } & \multicolumn{5}{c}{ Parameters } \\
\cline { 2 - 5 } & Feed intake $(\mathrm{kg})$ & Body weight $(\mathrm{kg})$ & Feed Conversion & Viability $(\%)$ \\
\hline $\mathrm{T} 1$ & $1.234 \mathrm{a}$ & 1.490 & $2.02 \mathrm{a}$ & 100 \\
$\mathrm{~T} 2$ & $1.261 \mathrm{a}$ & 1.533 & $1.96 \mathrm{a}$ & 99.34 \\
$\mathrm{~T} 3$ & $1.131 \mathrm{~b}$ & 1.491 & $1.92 \mathrm{a}$ & 100 \\
$\mathrm{~T} 4$ & $0.977 \mathrm{c}$ & 1.426 & $1.73 \mathrm{~b}$ & 100 \\
\hline $\mathrm{CV}$ & 6.73 & 4.93 & 9.25 & 0.40 \\
P value & $<0.01$ & 0.0792 & 0.0317 & 0.870 \\
\hline
\end{tabular}

The means with different letters are significantly different by Scott Knott's test $5 \%$ (P value $<0.05)$.

T1: diet based on ground corn and soybean meal. T2: diet based ground sorghum and soybean meal. T3: diet based whole grain sorghum and soybean meal. T4: diet based whole grain sorghum and concentrate separated in the feeder (free choice feeding).

No significant difference was observed between treatments for the weekly weight gain and viability. However, the best feed conversion was observed in the treatment with whole grain sorghum and concentrate separated in the feeder (T4), reflecting a lower feed intake during the analyzed period. Garcia et al. (2013) also did not observe differences in the weight gain of broilers fed diets based on increasing levels of sorghum in comparison to corn diets. However, these weight gain data with no significant difference diverge from Arroyo et al. (2012), who observed a higher weight gain in geese fed diets based on whole sorghum when compared to corn.

Analyzing the data in Table 3, which shows the results of broilers from 28 to 35 days of age, no difference was observed between feed intake and viability between treatments at 35 days of age. However, the lowest weight gain and highest feed conversion were also observed in the treatment with whole grain sorghum and concentrated in the feeder (T4). 
This lower weight gain in the second week is in accordance with Arroyo et al. (2012), who observed a lower weight gain in geese fed whole grain sorghum and concentrate in the second week of the experiment. In contrast, the higher feed conversion in $\mathrm{T} 4$ differs from the observed feed conversion found by Arroyo et al. (2012) in geese fed whole grain sorghum and concentrate in the second week of the experiment.

Table 4 shows the results of feed intake, live weight, feed conversion, and viability in the period from 35 to 42 days of age in all treatments. No feed intake difference was observed between treatments with corn and soybean meal (T1) and with whole grain sorghum and concentrate separated in the feeder (T4). The highest feed intake was observed in these treatments. Similarly, no difference $(p>0.05)$ was observed in the feed intake between the treatments with ground sorghum and soybean meal (T2) and whole grain sorghum and soybean meal (T3), which showed the lowest observed intakes. However, a difference was observed in the feed intake between T4 (free choice feeding), which presented the highest intake, and $\mathrm{T} 3$.

Table 3. Performance of Cobb 500 broilers of 28 to 35 days submitted to different diets, Uberlândia, 2014.

\begin{tabular}{ccccc}
\hline \multirow{2}{*}{ Diets } & \multicolumn{4}{c}{ Parameters } \\
\cline { 2 - 5 } & Feed intake $(\mathrm{kg})$ & Body weight $(\mathrm{kg})$ & Feed Conversion & Viability $(\%)$ \\
\hline $\mathrm{T} 1$ & 1.337 & $2.284 \mathrm{a}$ & $1.68 \mathrm{a}$ & 100 \\
$\mathrm{~T} 2$ & 1.311 & $2.311 \mathrm{a}$ & $1.69 \mathrm{a}$ & 99.32 \\
$\mathrm{~T} 3$ & 1.254 & $2.326 \mathrm{a}$ & $1.50 \mathrm{a}$ & 100 \\
$\mathrm{~T} 4$ & 1.401 & $2.141 \mathrm{~b}$ & $2.00 \mathrm{~b}$ & 100 \\
\hline $\mathrm{CV}$ & 6.58 & 4.50 & 15.79 & 0.90 \\
P value & 0.3332 & 0.0092 & 0.0164 & 0.4098 \\
\hline
\end{tabular}

The means with different letters are significantly different by Scott Knott's test 5\% (P value $<0.05)$.

T1: diet based on ground corn and soybean meal. T2: diet based ground sorghum and soybean meal. T3: diet based whole grain sorghum and soybean meal. T4: diet based whole grain sorghum and concentrate separated in the feeder (free choice feeding).

Table 4. Performance of Cobb 500 broilers of 35 to 42 days submitted to different diets, Uberlândia, 2014.

\begin{tabular}{ccccc}
\hline \multirow{2}{*}{ Diets } & \multicolumn{4}{c}{ Parameters } \\
\cline { 2 - 5 } & Feed intake $(\mathrm{kg})$ & Body weight $(\mathrm{kg})$ & Feed Conversion & Viability (\%) \\
\hline $\mathrm{T} 1$ & $1.442 \mathrm{a}$ & $3.178 \mathrm{a}$ & 1.62 & 100 \\
$\mathrm{~T} 2$ & $1.251 \mathrm{~b}$ & $3.086 \mathrm{a}$ & 1.62 & 99.35 \\
$\mathrm{~T} 3$ & $1.204 \mathrm{~b}$ & $3.074 \mathrm{a}$ & 1.62 & 100 \\
$\mathrm{~T} 4$ & $1.422 \mathrm{a}$ & $2.967 \mathrm{~b}$ & 1.76 & 100 \\
\hline $\mathrm{CV}$ & 4.93 & 3.67 & 9.52 & 0.90 \\
P value & $<0.001$ & 0.0173 & 0.2704 & 0.4098 \\
\hline
\end{tabular}

The means with different letters are significantly different by Scott Knott's test $5 \%$ (P value $<0.05)$.

T1: diet based on ground corn and soybean meal. T2: diet based ground sorghum and soybean meal. T3: diet based whole grain sorghum and soybean meal. T4: diet based whole grain sorghum and concentrate separated in the feeder (free choice feeding). 
These results differ from those found by Erener et al. (2003), who observed that the feed intake in the period from 35 to 42 days of age of broilers was not significantly different between treatments with whole grain wheat and whole grain wheat in the free choice system.

We also did not observe differences between feed conversion and viability in the analyzed period. These results are in accordance with those found by Fernandes et al. (2013), who observed no statistical differences at 42 days in the performance of broilers fed whole grain and ground sorghum-based diets. These authors also verified that the viability at 42 days was not affected by sorghum particle size.

In this study, no significant differences $(p>0.05)$ were observed for the average values of live weight between T1, T2, and T3, which is in accordance with the results found by Carolino (2012), who observed no differences in the live weight of broilers at 42 days between treatments with whole and ground sorghum.

Table 5 shows the results of the yield of cuts of broilers at 42 days of age for all treatments. The lowest yields of the breast with and without bone were significantly observed in T4, with no significant differences between the other treatments. Similarly, no significant differences were observed for the live weight at 42 days between T1, T2, and T3. These results differ from those found by Carolino (2012), who found that birds fed whole grain sorghum had a significantly lower yield when compared to those fed ground grain sorghum.

Table 5. Yield of cuts of cobb 500 broilers at 42 days in different diets, Uberlândia, 2014.

\begin{tabular}{cccccccc}
\hline \multirow{2}{*}{ Diets } & \multicolumn{7}{c}{ Parameters } \\
\cline { 2 - 7 } & $\begin{array}{c}\text { BWSB } \\
(\%)\end{array}$ & $\begin{array}{c}\text { BWOSB } \\
(\%)\end{array}$ & $\begin{array}{c}\mathrm{D} \\
(\%)\end{array}$ & $\begin{array}{c}\mathrm{W} \\
(\%)\end{array}$ & $\begin{array}{c}\mathrm{T} \\
(\%)\end{array}$ & $\begin{array}{c}\mathrm{DT} \\
(\%)\end{array}$ & $\begin{array}{c}\text { AF } \\
(\%)\end{array}$ \\
\hline $\mathrm{T} 1$ & $28.40 \mathrm{a}$ & $25.30 \mathrm{a}$ & 12.33 & 7.56 & 9.27 & 21.60 & $1.10 \mathrm{a}$ \\
$\mathrm{T} 2$ & $29.24 \mathrm{a}$ & $25.10 \mathrm{a}$ & 12.02 & 7.36 & 9.62 & 21.65 & $0.98 \mathrm{a}$ \\
$\mathrm{T} 3$ & $28.53 \mathrm{a}$ & $24.65 \mathrm{a}$ & 12.20 & 7.84 & 9.37 & 21.56 & $1.04 \mathrm{a}$ \\
$\mathrm{T} 4$ & $24.95 \mathrm{~b}$ & $21.29 \mathrm{~b}$ & 12.40 & 7.60 & 9.58 & 21.98 & $1.95 \mathrm{~b}$ \\
\hline CV & 6.47 & 7.74 & 14.23 & 5.17 & 4.61 & 8.20 & 30.47 \\
P value & 0.0023 & 0.0039 & 0.9829 & 0.2459 & 0.4483 & 0.9752 & 0.0061 \\
\hline
\end{tabular}

The means with different letters are significantly different by Scott Knott's test $5 \%$ (P value $<0.05)$.

T1: diet based on ground corn and soybean meal. T2: diet based ground sorghum and soybean meal. T3: diet based whole grain sorghum and soybean meal. T4: diet based whole grain sorghum and concentrate separated in the feeder (free choice feeding). BWSB: breast with skin and bone. BWOSB: breast without skin and bone. D: drumstick. T:thighs. W: wings. DT: drumstick whit thighs. AF: abdominal fat.

The parameters drumstick, wing, thigh, and drumstick + thigh showed no significant differences between treatments, corroborating the parameters of feed conversion at 42 days of age, which did not present significant differences between treatments. A significant difference was observed in the abdominal fat only in T4 possibly due to a higher intake of concentrate when compared to the sorghum in the initial phase of the experiment from 21 to 25 days, which had a higher oil addition, allowing a higher deposition of abdominal fat. These results are different from those found by Erener et al. (2003), who did not find a significant difference between treatments of free choice feeding with whole grain wheat in the deposition of abdominal fat.

Table 6 shows the results of the bromatological composition of the pectoral muscle of birds at 42 
days of age for all treatments. In this sense, T4 presented the highest concentrations of ethereal extract and mineral matter when compared to the other treatments. This difference is probably due to a higher concentrate intake in relation to sorghum registered in the first three days after starting T4. In this case, no sorghum intake was observed in this period, which may have determined a higher deposition of minerals and fat in the muscle tissue. No difference was observed between treatments for crude protein. In addition, T3 presented the lowest dry matter concentration (28.75\%), differing significantly from the other treatments.
According to Bogosavljević-Bošković et al. (2010), the bromatological composition of the pectoral muscle, especially proteins and lipids, is an important parameter of nutritional quality. The parameters found for the crude protein composition of the pectoral muscle are in agreement with those mentioned by Marcu et al. (2009) and Suchý et al. (2002), who found values above $22.50 \%$ for total proteins. The values of total fat mentioned by these authors are between 1.59 and $2.60 \%$ for the pectoral muscle, thus diverging from the results found in this experiment probably because the breast samples were processed with skin, leading to higher levels (between 5.08 to $7.47 \%$ fat).

Table 6. Bromatological composition of the Cobb 500 broiler breast muscle at 42 days of age, Uberlândia, 2014.

\begin{tabular}{ccccc}
\hline \multirow{2}{*}{ Diets } & \multicolumn{4}{c}{ Parameters } \\
\cline { 2 - 5 } & EE (\%) & CP $(\%)$ & MM (\%) & DM (\%) \\
\hline T1 & $6.01 \mathrm{~b}$ & 23.95 & $1.23 \mathrm{~b}$ & $30.91 \mathrm{a}$ \\
T2 & $5.27 \mathrm{~b}$ & 23.21 & $1.20 \mathrm{~b}$ & $30.52 \mathrm{a}$ \\
T3 & $5.08 \mathrm{~b}$ & 22.81 & $1.22 \mathrm{~b}$ & $28.75 \mathrm{~b}$ \\
T4 & $7.47 \mathrm{a}$ & 24.16 & $1.39 \mathrm{a}$ & $32.61 \mathrm{a}$ \\
\hline CV & 9.54 & 4.83 & 8.21 & 5.89 \\
P value & $<0.0100$ & 0.1715 & 0.0128 & 0.0133 \\
\hline
\end{tabular}

The means with different letters are significantly different by Scott Knott's test $5 \%$ (P value $<0.05)$.

T1: diet based on ground corn and soybean meal. T2: diet based ground sorghum and soybean meal. T3: diet based whole grain sorghum and soybean meal. T4: diet based whole grain sorghum and concentrate separated in the feeder (free choice feeding). EE: ethereal extract, CP: crude protein, MM: mineral matter, DM: dry matter.

Table 7 shows the results of the bromatological composition of the drumstick and thigh of birds at 42 days of age for all treatments. The highest concentration of ethereal extract was verified in T4, coinciding with the data of higher concentration of ethereal extract found for this same treatment in the bromatological composition of the breast. A higher concentrate intake in the first few days of the experiment is assumed to favor drumstick and thigh fat accumulation, in addition to other body parts (Table 5), which provided the highest ethereal extract contents shown by the laboratory tests. Concomitantly, no statistically significant difference was found between treatments for crude protein, thus being similar to the results of this parameter for the bromatological composition of breast (Table 5 ). These results are similar to those obtained by Carolino et al. (2014), who also did not observe differences in crude protein between treatments with whole grain sorghum versus ground sorghum. 
Table 7. Bromatological composition of the Cobb 500 broiler thigh and drumstick at 42 days of age, Uberlândia, 2014.

\begin{tabular}{ccccc}
\hline \multirow{2}{*}{ Diets } & \multicolumn{4}{c}{ Parameters } \\
\cline { 2 - 5 } & EE $(\%)$ & CP $(\%)$ & MM (\%) & DM (\%) \\
\hline T1 & $12.97 \mathrm{c}$ & 19.15 & $1.19 \mathrm{a}$ & $35.99 \mathrm{~b}$ \\
T2 & $15.07 \mathrm{~b}$ & 19.69 & $1.06 \mathrm{~b}$ & $37.35 \mathrm{~b}$ \\
$\mathrm{~T} 3$ & $10.97 \mathrm{~d}$ & 19.34 & $1.02 \mathrm{~b}$ & $36.09 \mathrm{~b}$ \\
T4 & $18.97 \mathrm{a}$ & 19.97 & $1.14 \mathrm{a}$ & $42.69 \mathrm{a}$ \\
\hline CV & 8.09 & 7.45 & 9.18 & 7.41 \\
P value & $<0.001$ & 0.7710 & 0.0379 & 0.0014 \\
\hline
\end{tabular}

The means with different letters are significantly different by Scott Knott's test 5\% (P value $<0.05)$.

T1: diet based on ground corn and soybean meal. T2: diet based ground sorghum and soybean meal. T3: diet based whole grain sorghum and soybean meal. T4: diet based whole grain sorghum and concentrate separated in the feeder (free choice feeding). EE: ethereal extract, CP: crude protein, MM: mineral matter, DM: dry matter.

The highest significant concentration of dry matter was observed in T4, which is in accordance with the data shown in Table 6 for this same variable. The highest concentrations of mineral matter were observed in $\mathrm{T} 1$ and $\mathrm{T} 4$, with no statistical difference between them. In addition, no statistical difference was observed between $\mathrm{T} 2$ and $\mathrm{T} 3$ for this parameter.

Figures 1, 2, and 3 show the daily intake of metabolizable energy, lysine, and methionine + cystine intakes of birds for T3 and T4 from 21 to 42 days of age.

The daily intake of metabolizable energy for T3 and T4 (Figure 1) in the regression equations are statistically different, even at the point of intersection of the polynomial trend lines. The significance of all regression equations of all graphs was verified using the $p$-value in the analysis of variance of the second-degree model and showed significance. The daily intakes of metabolizable energy for T4 were lower in the period from 21 to 29 days of age, but from 35 days of age, the birds of this treatment started to intake more metabolizable energy when compared to T3 in the same period. This inversion in the intake of metabolizable energy in T4 may probably have occurred due to the adaptation period of birds to the diet with sorghum and concentrate separated in the feeder since a higher sorghum intake was observed from 35 days of age when compared to concentrate intake, justifying the increased intake of metabolizable energy in this period. 
Figure 1. Metabolizable energy intake (kcal/day) of Cobb 500 males broiler at 21-42 days.

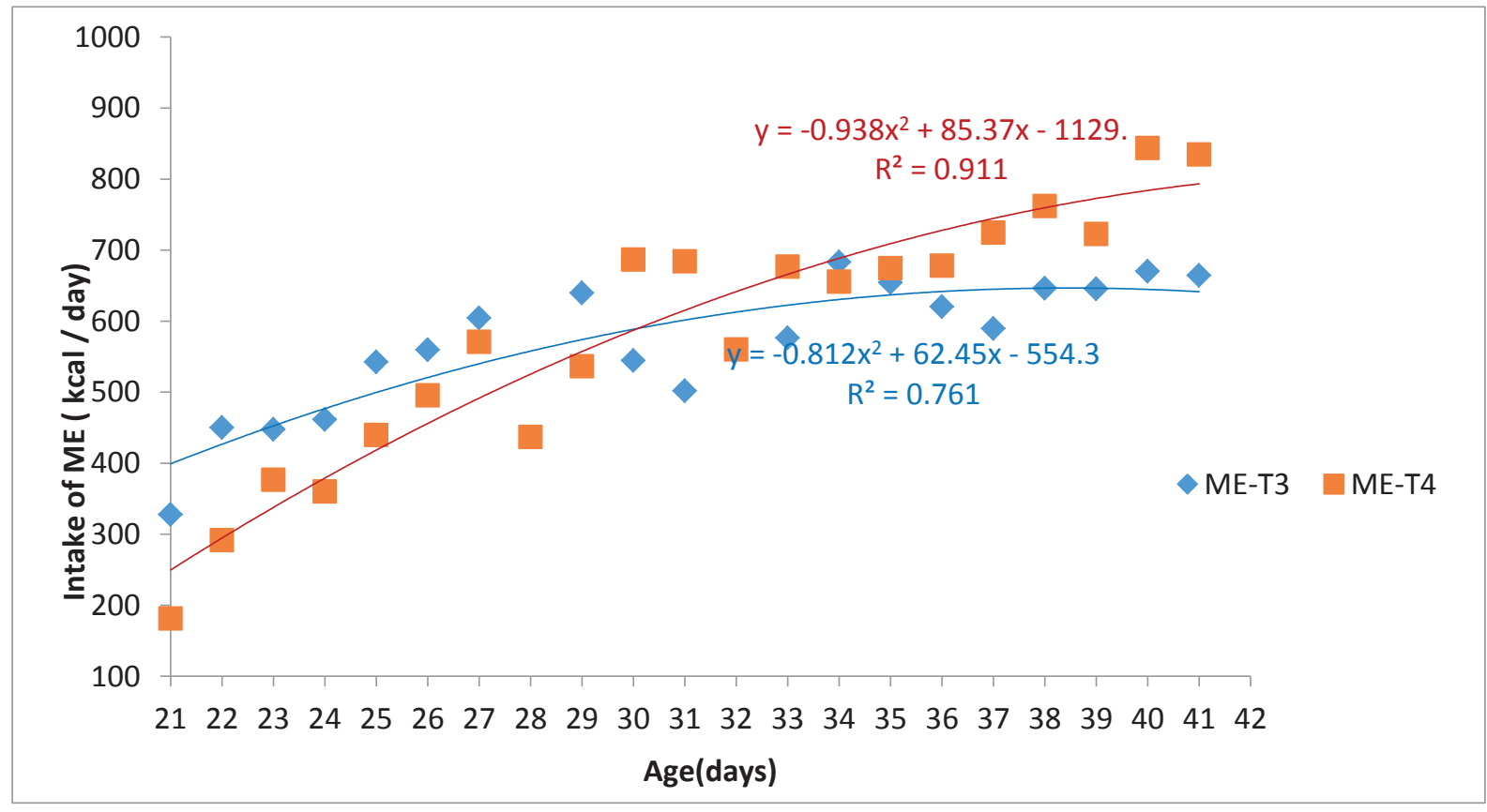

*Equation for a polynomial regression model. T1: diet based on ground corn and soybean meal. T2: diet based ground sorghum and soybean meal. T3: diet based whole grain sorghum and soybean meal. T4: diet based whole grain sorghum and concentrate separated in the feeder (free choice feeding).

The highest intake of metabolizable energy was observed at 42 days of age for T4 $(800 \mathrm{kcal} / \mathrm{bird} /$ day), one day before slaughtering the birds. The data of daily intake of metabolizable energy in $\mathrm{T} 3$ are in accordance with those found by Rostagno et al. (2011), who observed an increase in the intake of metabolizable energy at 21 days from $346 \mathrm{kcal} / \mathrm{bird} /$ day to $658 \mathrm{kcal} / \mathrm{bird} /$ day. This allows us to infer that birds can self-regulate their intake of metabolizable energy, ratifying the glucostatic theory, i.e. birds consume in order to satisfy their organic demands of metabolizable energy primarily to the detriment of the prandial needs of amino acids and other nutrients, as mentioned by some authors (FERKET; GERNAT, 2006; MAIORKA et al., 2002).

The data of daily intake of lysine (Figure 2) showed a significant difference between $\mathrm{T} 3$ and $\mathrm{T} 4$, with the highest intake of lysine observed in T3 during the entire experimental period. These higher intakes of lysine in T3 are in accordance with the higher live weight of birds in the same treatment when compared to T4 since lysine is metabolically used for deposition of body protein, especially in the breast (PACK, 1995). These data of intake of digestible lysine in T4 confirm the data obtained by Rostagno et al. (2011), who observed that the requirements of digestible lysine per bird decrease in the same period from 21 to 42 days of age, which is similar to that observed in the quadratic curve of T4. This behavior, expressed by the polynomial trend curve of T4, allows us to infer that if the birds of this treatment had been fed since the first day of age, with a longer adaptation period to this diet, we would probably observe an intake behavior of lysine per day very similar to that of digestible lysine of $\mathrm{T} 3$ since the birds of T4, with a shorter adaptation period to the diet, tended to show a behavior of selfregulation in the intake of digestible lysine. 
Figure 2. Lysine intake (gram/day) of Cobb 500 males broiler at 21-42 days.

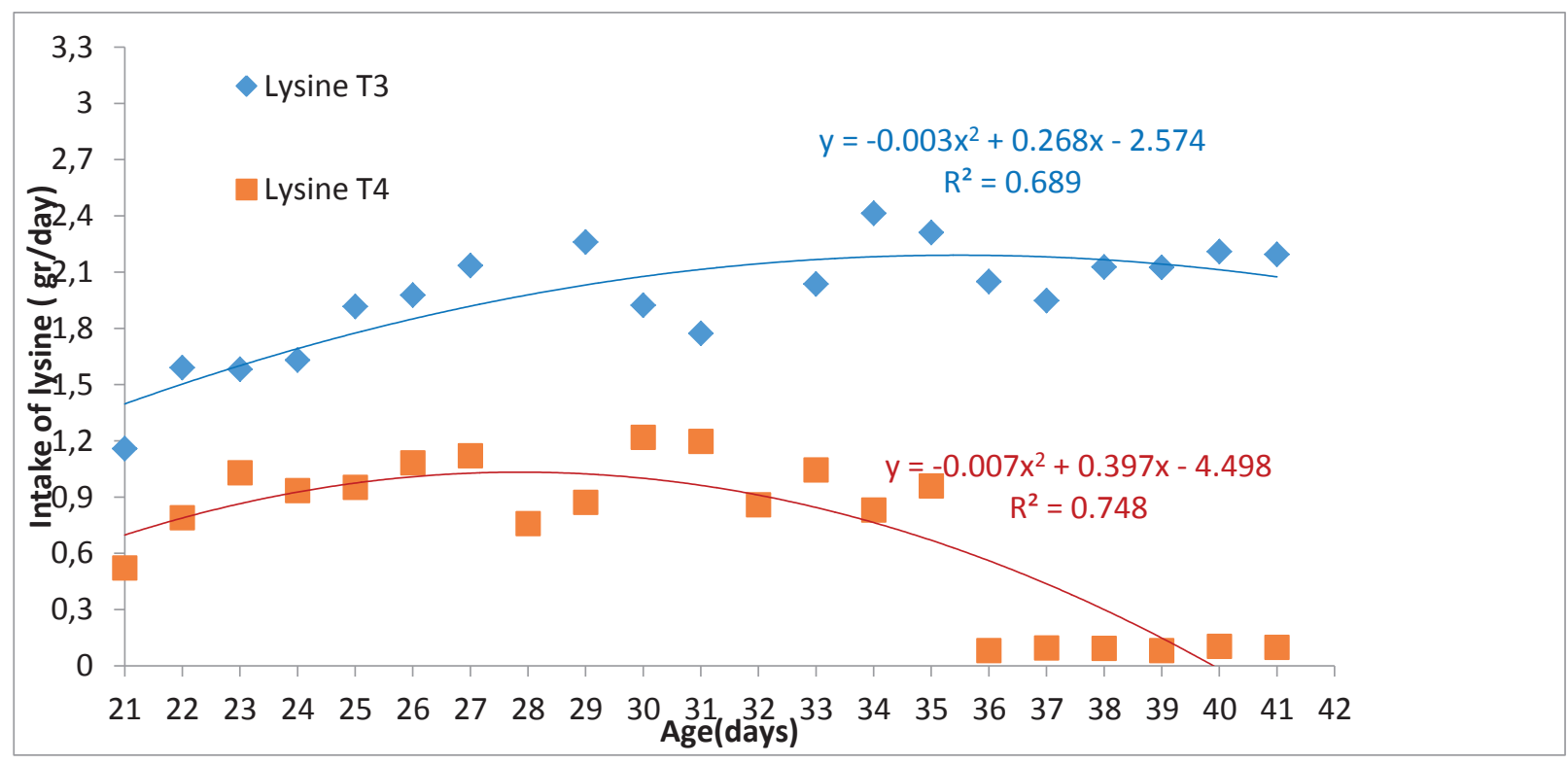

*Equation for a polynomial regression model. T1: diet based on ground corn and soybean meal. T2: diet based ground sorghum and soybean meal. T3: diet based whole grain sorghum and soybean meal. T4: diet based whole grain sorghum and concentrate separated in the feeder (free choice feeding).

Significant lower intakes of lysine were recorded in T4 from 36 days of age when a low intake of concentrate was observed in relation to whole grain sorghum, which may justify this behavior at that time (Figure 2). Low breast yields were also observed in $\mathrm{T} 4$ since the low intakes of lysine imply a low pectoral muscle deposition. In fact, Tesseraud et al. $(1999,2002)$ observed that low intakes of lysine and deficiencies of this amino acid affect muscle growth in broilers, being the growth of the pectoral muscle the most affected when compared to other muscles.

The lowest significant intakes of methionine + cystine (Figure 3 ) were found in T4 during the entire experimental period when compared to T3. These results are similar to the intake of lysine (Figure 2), in which the intake of concentrate was lower when compared to sorghum, especially at the beginning and end of the experiment since the concentrate has higher levels of lysine and methionine + cystine. However, despite the significant differences in the intake of methionine + cystine between treatments, the curves presented similarity, which implies that the intake trends of these amino acids are similar between treatments and induce to assume that birds have the ability to self-regulate their intake. In addition, the birds of $\mathrm{T} 3$ and $\mathrm{T} 4$ were adapted to a diet with corn bran and soybean meal prior to the experiment and these animals were submitted to diets with whole grain sorghum from 21 days of age, leading them to stress due to a change in diet, which probably contributes to the lower intakes of amino acid observed in $\mathrm{T} 4$ in relation to T3. However, despite the dietary stress and the short period of adaptation of the birds to the new diet, they presented an intake behavior of energy and amino acid similar to that observed in $\mathrm{T} 3$. Therefore, if the birds had been fed from the first day of age with this whole grain sorghum-based diet in a free choice feeding system, they probably would present intakes of energy and amino acids without significant differences between $\mathrm{T} 3$ and $\mathrm{T} 4$ due to their longer adaptation period to the diet. In fact, Silva et al. (2014) observed that broiler chicks fed whole grain sorghum from the first day of age 
presented the same performance as chicks fed ground sorghum. Faced with these considerations, we suggest that new experiments can be conducted with whole grain sorghum in a free choice feeding system from the first day of age, ratifying their behavior of self-regulation for intake in free choice systems from the first day of age.

Figure 3. Methionine+ cystine intake (gram/day) of Cobb 500 males broiler at 21-42 days.

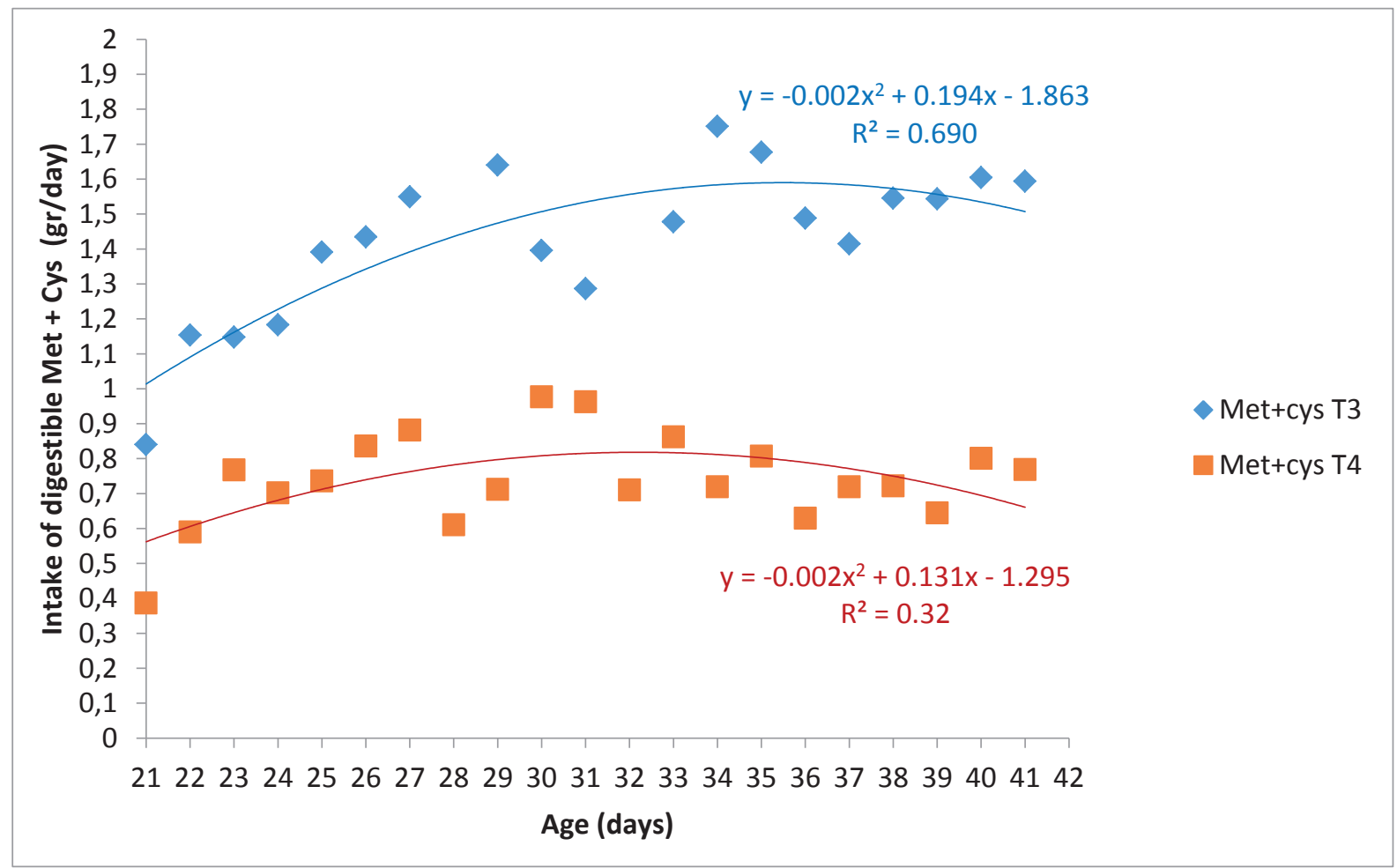

*Equation for a polynomial regression model. T1: diet based on ground corn and soybean meal. T2: diet based ground sorghum and soybean meal. T3: diet based whole grain sorghum and soybean meal. T4: diet based whole grain sorghum and concentrate separated in the feeder (free choice feeding).

\section{Conclusion}

The use of diets with whole grain or ground sorghum for broilers during the period from 21 to 42 days of age promotes the same results of zootechnical performance, yield, and bromatological composition of cuts when compared to corn diets. In addition, in diets in a free choice feeding system, with whole grain sorghum and concentrate in the period from 21 to 42 days of age, birds can self-regulate their intake of energy and amino acids such as lysine and methionine + cystine.

The Committee on Ethics in the Use of Animals approved the protocol under the following registry:
CEUA/UFU-Federal University of Uberlândia $023 / 14$.

\section{References}

ARROYO, J.; AUVERGNE, A.; DUBOIS, J. P.; LAVIGNE, F.; BIJJA, M.; FORTUN-LAMOTHE, L. Influence of feeding sorghum on the growth, gizzard development and carcass traits of growing geese. Animal, London, v. 6, n. 10, p. 1583-1589, 2012.

BIAGI, J. D. Implicações da granulometria de ingredientes na qualidade de peletes e na economia da produção de rações. In: SIMPÓSIO SOBRE GRANULOMETRIA DE INGREDIENTES E RAÇÕES PARA SUÍNOS E AVES, 1998, Concórdia. Anais... Concórdia: EMBRAPA/ 
CNPSA, 1998. p. 57-70.

BOGOSAVLJEVIĆ-BOŠKOVIĆ, S.; PAVLOVSKI, Z.; PETROVIĆ, M. D.; DOSKOVIĆ, V.; RAKONJAC, S. Broiler meat quality: proteins and lipids of muscle tissuereview. African Journal of Biotechnology, Nairobi, v. 9, n. 54, p. 9177-9182, 2010.

CAROLINO, A. C. X. G. Morfometria do trato gastrintestinal e qualidade da carcaça de frangos de corte alimentados com sorgo grão inteiro. 2012. Dissertação (Mestrado em Ciências Veterinárias) - Universidade Federal de Uberlândia, Uberlândia.

CAROLINO, A. C. X. G.; SILVA, M. C. A.; LITZ, F. H.; FAGUNDES, N. S.; FERNANDES, E. A. Rendimento e composição de carcaça de frangos de corte alimentados com dietas contendo sorgo grão inteiro. Bioscience Journal, Uberlândia, v. 30, n. 4, p. 1139-1148, 2014.

CARVALHO, F. M.; FIÚZA, M. A.; LOPES, M. A. Determinação de custos como ação de competitividade: estudo de um caso na avicultura de corte. Ciência e Agrotecnologia, Lavras, v. 32, n. 3, p. 908-913, 2008.

DOZIER, W. A. Reducing utility cost in the feed mill. Watt Poultry, Kansas City, v. 53, n. 1, p. 40-44, 2002.

ERENER, G.; OCAK, N.; OZTURK, E.; OZDAS, A. Effect of different choice feeding methods based on whole wheat on performance of male broiler chickens. Animal Feed Science and Technology, Amsterdam, v. 106, n. 1-4, p. 131-138, 2003.

FARUK, M. U. L'évaluation de l'alimentation mélangée et séquentielle à base de matières premières localement disponibles sur les performances des poules pondeuses en France et au Nigeria. 2010. Tese (Doutorado em Ciências da Vida) - Université François, Tours.

FERKET, P. R.; GERNAT, A. G. Factors that affect feed intake of meat birds: a review. International Journal of Poultry Science, Faisalabad, v. 5, n. 10, p. 905-911, 2006.

FERNANDES, E. A.; PEREIRA, W. J. S.; HACKENHAAR, L.; RODRIGUES, R. M.; TERRA, R. The use of whole grain sorghum in broiler feeds. Revista Brasileira de Ciência Avícola, Campinas, v. 15, n. 3, p. 217-222, 2013.

FERREIRA, D. F. SISVAR: Um programa para análise e ensino de estatística. Revista Symposium, v.6, n. 2, p.3641,2008

GARCIA, R. G.; MENDES, A. A.; ALMEIDA PAZ, I. C. L.; KOMIYAMA, C. M.; CALDARA, F. R.; NÄÄS, I. A.; MARIANO, W. S. Implications of the use of sorghum in broiler production. Brazilian Poultry Science, Campinas, v. 15 , n. 3 , p. $257-262,2013$.
LIU, S. Y.; TRUONG, H. H.; SELlE, P. H. Wholegrain feeding for chicken-meat production: possible mechanisms driving enhanced energy utilisation and feed conversion. Animal Production Science, Melbourne, v. 55, n. 5, p. 559-572, 2014.

MAIORKA, A.; BOLELI, I. C.; MACARI, M. Desenvolvimento e reparo da mucosa intestinal. In: MACARI, M.; FURLAN, R. L.; GONZÁLES, E. (Ed.). Fisiologia da digestão e absorção das aves. Campinas: Fundação Apinco de Ciência e Tecnologia Avícolas, 2002. p. 113-124.

MARCU, A.; VĂCARU-OPRIŞ, I.; MARCU, A. The influence of feed protein and energy level on meat chemical composition from different anatomical regions at Cobb 500 hybrid. Zootehnie si Biotecnologii, Timisoara, v. 42, n. 1, p. 147-150, 2009.

PACK, M. Proteína ideal para frango de corte. Conceitos e posição atual. In: CONFERÊNCIA APINCO DE TECNOLOGIA AVÍCOLA, 1995, Curitiba. Anais... Curitiba: FACTA, 1995. p. 95-110.

POUSGA, S.; BOLY, H.; OGLE, B. Choice feeding of poultry: a review. Livestock Research for Rural Development, Roma, v. 17, n. 4, p.45-46, 2005.

ROSTAGNO, H. S.; ALBINO, L. F.; DONZELE, J. L.; GOMES, P. C.; OLIVEIRA, R. F.; LOPES, D. C.; FERREIRA, A. S.; BARRETO, S. L. T.; EUCLIVES, R. F. Tabelas brasileiras para aves e suínos: composição de alimentos e exigências nutricionais. 3. ed. Viçosa, MG: UFV/DZO, 2011. $252 \mathrm{p}$.

SILVA, D. J.; QUEIROZ, A. C. Análise de alimentos: métodos químicos e biológicos. 3. ed. Viçosa: UFV, 2002. $235 \mathrm{p}$.

SILVA, M. C. A.; CAROLINO, A. C. X. G.; LITZ, F. H.; FAGUNDES, N. S.; FERNANDES, E. A. Sorgo grão inteiro na ração pré-inicial de pintinhos de corte e os efeitos sobre o desenvolvimento. Enciclopédia Biosfera - Centro Científico Conhecer, Goiânia, v. 10, n. 18, p. 2769-2782, 2014.

SUCHÝ, P.; JELÍNEK, P.; STRAKOVÁ, E.; HUCL, J. Chemical composition of muscles of hybrid broiler chickens during prolonged feeding. Czech Journal of Animal Science, Praga, v. 47, n. 12, p. 511-518, 2002.

TESSERAUD, S.; LE BIHAN-DUVAL, E.; PERESSON, R.; MICHEL, J.; CHAGNEAU, A. M. Response of chick lines selected on carcass quality to dietary lysine supply: live performance and muscle development. Poultry Science, Oxford, v. 78, n. 1, p. 80-84, 1999.

TESSERAUD, S.; TEMIM, S.; LE BIHAN-DUVAL, E.; CHAGNEAU, A. M. Increased responsiveness to dietary 
lysine deficiency of pectoralis major muscle protein alimentos para bovinos. Viçosa, MG: UFV/DZO; DPI, turnover in broilers selected on breast development. Journal of Animal Science, Champaign, v. 79, n. 4, p. 927-933, 2002.

VALADARES FILHO, S. C.; ROCHA JUNIOR, V. R.; CAPELLE, E. R. Tabelas brasileiras de composição de 2001. $297 \mathrm{p}$.

ZANOTTO, D. L.; BRUM, P. A. R.; GUIDONI, A. L. Granulometria do milho da dieta e desempenho de frangos. In: CONFERÊNCIA APINCO DE CIÊNCIA E TECNOLOGIA AVÍCOLAS, 1996, Curitiba. Anais... Campinas: FACTA, 1996, p. 19. 